\title{
Clinical and Biomarkers Difference in Prepartum and Postpartum Eclampsia
}

\author{
Yifru Berhan ${ }^{1}$, Gezahegn Endeshaw ${ }^{1}$
}

\begin{abstract}
BACKGROUND: There is a large body of literature which assessed the incidence and risk factors of eclampsia, but little was done in assessing the association of clinical features and biological markers with prepartum and postpartum eclampsia.

METHODS: A total of 361 eclamptic women admitted to three teaching hospitals between 2008 and 2013 were included in this analysis. A comparative analysis was done for several clinical and biological variables to assess their association with prepartum and postpartum eclampsia.

RESULTS: The overall incidence of eclampsia was $1.2 \%$ (prepartum $71 \%$ and postpartum 29\%). The majority of women with prepartum eclampsia were young, primigravida, more hypertensive, symptomatic and proteinuric. Conversely, the majoritys of the women with post-partum eclampsia were adult, multiparous, carrying pregnancy to term, anemic, thrombocytopenic, and with hepatic dysfunction. The commonest severity symptom (headache) was less common in postpartum eclamptic women.

CONCLUSION: The incidence of eclampsia was among the highest in the world. And, the analysis has shown that the clinical and biochemical spectrum of prepartum and postpartum eclampsia were apparently different. The majority of the women who developed postpartum eclampsia were multiparous and adult. Derangement of biomarkers was also more common in women with postpartum eclampsia.
\end{abstract}

KEYWORDS: clinical features, comparative analysis, Ethiopia, incidence, organs dysfunction, prepartum, postpartum

DOI: http://dx.doi.org/10.4314/ejhs.v25i3.9

\section{INTRODUCTION}

Eclampsia is one of the commonest causes of maternal and perinatal morbidity and mortality worldwide, the majority being in developing countries $(1,2)$. It may complicate $2 \%$ to $3 \%$ of severely preeclamptic women not given anticonvulsant prophylaxis, and about $0.6 \%$ of those women receiving the anticonvulsant prophylaxis $(3,4)$. The overall incidence of eclampsia in developed and developing countries is estimated to be 1.6 to 10 and 6 to 157 per 10,000 deliveries, respectively $(3,5,6)$.

Eclampsia is characterized by the occurrence of generalized tonic-clonic seizure and/or coma in pregnant or postpartum women with preeclampsia, and is not caused by epilepsy or other convulsive disorders (7-9). It is well known that eclampsia can occur during pregnancy (antepartum), during labor and delivery (intrapartum), and after delivery (postpartum) $(10,11)$.

To date, however, there are no reliable biological tests to predict which pregnant or postpartum women will have preeclampsia/eclampsia (12). Clinical features and laboratory findings are also nonspecific but commonly used as a surrogate marker for the effect of the disease on organs/systems and as a warning sign for eclampsia (13). The challenge is that eclampsia can occur without clinical or biological evidences of preeclampsia (14-16).

There is a large body of literature on eclampsia, which described its incidence before, during and after delivery, factors associated with its occurrence and the risks of maternal and perinatal mortality taking the overall eclampsia as a denominator (7,17-21). However, there is a

${ }^{1}$ College of Medicine and Health Sciences, Hawassa University, Ethiopia

Corresponding Author: Yifru Berhan, email: yifrub@yahoo.com 
paucity of data that assessed the risk factors and its complications disaggregated by onset of eclampsia.

One study investigated maternal and obstetric factors associated with delayed and early postpartum eclampsia (22). Only delayed eclampsia cases were also compared with preeclamptic mothers with no eclampsia in the postpartum period (23). Other studies assessed only the magnitude of fetal and/or maternal mortality by type of eclampsia $(24,25)$. In another study, some clinical features and proteinuria were compared in 46 antepartum and postpartum eclamptic women (26). Recurrence of convulsion in different types of anticonvulsant was assessed by different types of eclampsia (27). Antepartum and intrapartum eclampsia were also assessed for mode of delivery (28). Relatively, better characterization of eclampsia by type was done in a Scandinavian study (29).

To our knowledge, this is the first study that investigated several variables in relation to prepartum and postpartum eclampsia. Thus, the objective of the study was to assess the association of selected clinical features and biological markers with prepartum and postpartum eclampsia.

\section{METHODS}

Study design, setting and participants: The current analysis was performed from a six year retrospective cohort study database, which was collected from three university teaching hospitals (Hawassa, Hosanna and Yirgalem) in the South regional state of Ethiopia. A comparative analysis (prepartum vs postpartum eclampsia) was done for several clinical and biological variables. All eligible women with eclampsia admitted to the study hospitals during the study period (2008 to 2013) were included. The exclusion criterion was lost or incomplete data.

The study hospitals were functioning as referral centers for the region and teaching center for public universities and private health colleges. In these hospitals, eclampsia was diagnosed with the onset of generalized tonic-clonic seizure and/or coma in pregnant or postpartum women commonly with clinical and/or laboratory features of preeclampsia. The most senior person's (gynecologist, resident or general practitioner) clinical assessments and decisions were taken as a final source of data for this analysis.
The commonly assessed clinical features for women with eclampsia were hypertension, headache, blurring of vision, epigastric pain, vomiting, urine output, bleeding tendency and generalized body swelling. Among others, dipstick and microscopic examination of urine, liver and renal function tests, and complete blood count were routinely performed in all study hospitals.

Variables and data collection: Some of the variables assessed in association with the onset of eclampsia were: maternal age, parity, gestational age, prenatal care, number of fetuses, severity symptoms of HDP, degree of hypertension, episodes of convulsion, urine output, proteinuria, hemoglobin level, platelet count, creatinine level, serum oxaloacetic transaminase (SGOT) level, type of anticonvulsant or antihypertensive given, mode of delivery, fetal birth weight, perinatal and maternal outcome.

The detail data were retrieved from patients' charts. Each patient's chart was accessed after identifying the eclampsia cases by their card number in the delivery log book. A structured data collecting format was prepared and used to abstract relevant data from the included patients' charts. The data were abstracted by nine trained nurse data collectors (three for each hospital).

Data analysis: Data were entered into a computer data analysis software program (Epi Info 7) to perform a comparative analysis. We used frequencies and proportions to describe the characteristics of the included variables with stratification by total eclampsia, prepartum and postpartum onset of eclampsia. A statistically significant association was considered when the pvalue was $<0.05$. A flow diagram was used to select the study participants and a bar graph was constructed to show the proportion of eclampsia stratified by onset.

Operational definitions: Onset of eclampsia was classified based on occurrence of first convulsion as antepartum (before onset of labor), intrapartum (during labor and delivery), and postpartum (after delivery and before end of purperium). It was also reclassified as early onset $(<34$ weeks of gestation) and late onset $(>=34$ weeks of gestation). The postpartum eclampsia cases were also reclassified as early postpartum $(<48$ hours after delivery) and late postpartum ( $>=48$ hours and $<6$ weeks after delivery). 
For the purpose of this analysis, however, the antepartum and intrapartum onset of eclampsia were merged to prepartum eclampsia. This was done taking into account that the baby and placenta were still in utero in both antepartum and intrapartum onset of eclampsia. One of the etiologies incriminated for occurrence of preeclampsia/eclampsia is placental pathology (8). As a result, this study defines prepartum eclampsia in women who developed generalized tonic-clonic seizure before the delivery and after 28 weeks of gestation. Women included as postpartum eclampsia were those who developed generalized tonic-clonic seizure after the delivery of at least a 28 week gestational age fetus and before 6 weeks of the postpartum period.

Eclamptic women's systolic and diastolic blood pressures (BP) after admission were grouped as $<160$ and $>=160 \mathrm{mmHg}$, and $<110$ and $>=110 \mathrm{mmHg}$, respectively. The laboratory results were also dichotomized in order to determine their association with prepartum and postpartum eclampsia. Significant proteinuria defined that the qualitative test revealed +2 and above or +1 if the specific gravity was <1.020. Serum glutamicoxaloacetic transaminase (SGOT) level raised by $>=2$-fold from the baseline and creatinine level $>=1 \mathrm{mg} / \mathrm{dl}$ were considered as significantly raised. Platelet count $<100,000 / \mathrm{mm} 3$ and hemoglobin level $<12+\mathrm{gm} / \mathrm{dl}$ were taken as severe thrombocytopenia and anemia, respectively.

Women with an age range of 15-24 years and 25-49 years were categorized as youth and adult, respectively (30). Youth and young women, primigravida and nulliparous were used interchangeably. The term prepartum and predelivery, postpartum and post-delivery were also used interchangeably.

Ethical consideration: Hawassa University College of Medicine and health sciences, institutional review board (IRB) gave us the ethical clearance to conduct and publish this research. Since the study was retrospective by design, written consent from patients was not required. Patient records were anonymized and deidentified by excluding identifiers from data collection format prior to analysis. Furthermore, anonymity was secured by analyzing and presenting the data in aggregate.

\section{RESULTS}

During the study period, there were 30,750 deliveries in all study hospitals (Figure 1). Of which, 1098(3.6\%) women were diagnosed to have hypertensive disorders of pregnancy (HDP). Out of the total HDP cases, 373 were registered as eclampsia. Twelve cases of eclampsia were excluded from analysis due to incomplete or lost data. Finally, 361 women with eclampsia were included for this analysis $(1.2 \%$ of the total deliveries and $33 \%$ of the total HDP). These women were again regrouped as prepartum and postpartum eclampsia, 256 (71\%) and 105 (29\%), respectively. 


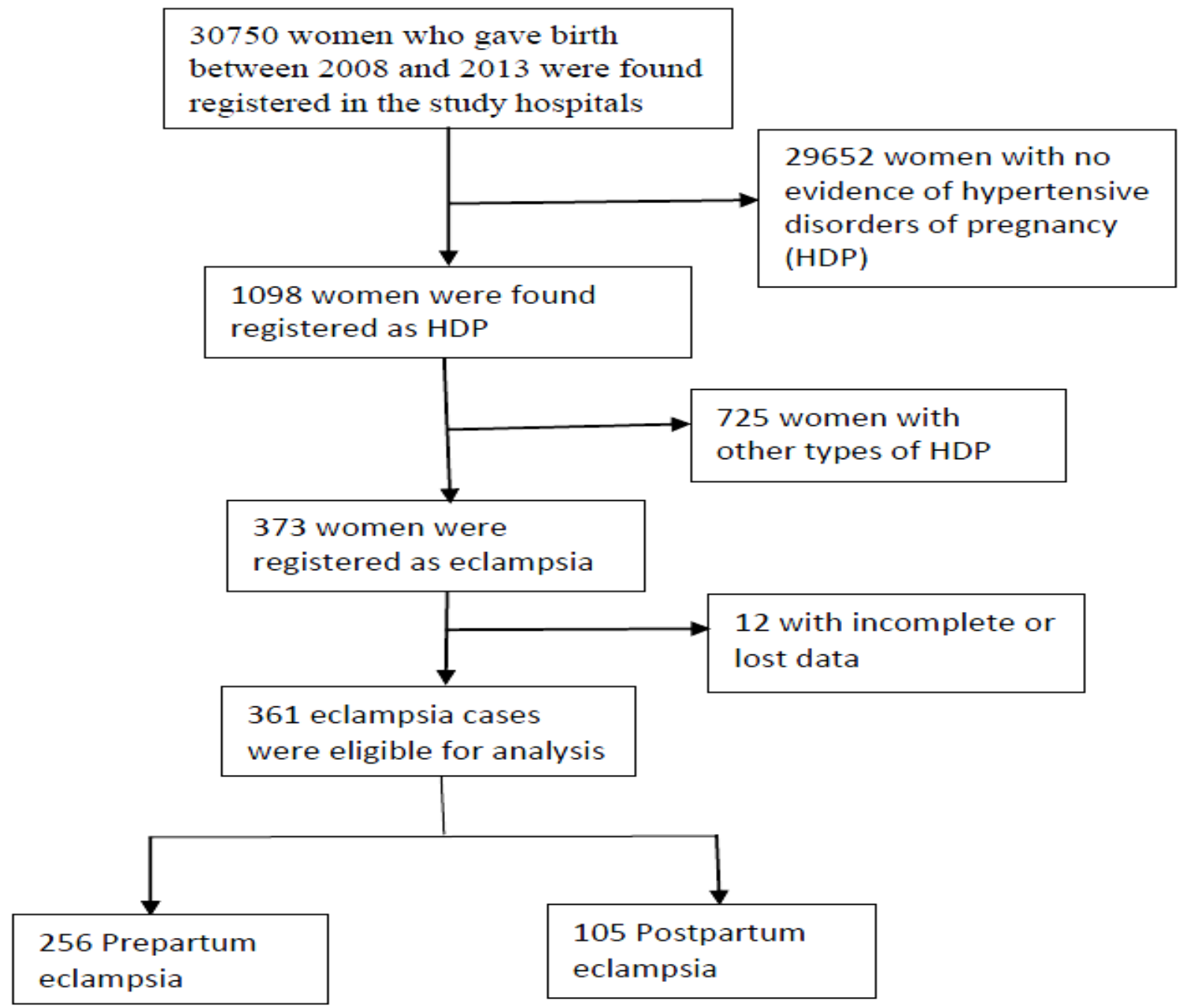

Figure 1: Flow diagram showing the study population selection

Figure 2 shows the summary of the included eclamptic women as categorized by occurrence of first convulsion in relation to the gestational age and delivery. Out of 361 eclamptic women, the proportion of antepartum, intrapartum and postpartum eclampsia was $47 \%, 24 \%$ and $29 \%$, respectively. In terms of gestational age, the early ( $<34$ weeks $)$ and late $(>=34$ weeks $)$ onset eclampsia cases were $18 \%$ and $82 \%$, respectively.
Specific to postpartum eclampsia, early $(<48$ hours after birth) and late/atypical ( $>=48$ hours after birth) onset accounted for $79 \%$ and $21 \%$, respectively. The range of late onset eclampsia was 60 hours to 10 days from the time of delivery; five patients developed eclampsia on the $10^{\text {th }}$ postpartum day. In $97 \%$ of the total eclamptics, the convulsion occurred at home or on the way to the study hospitals. 


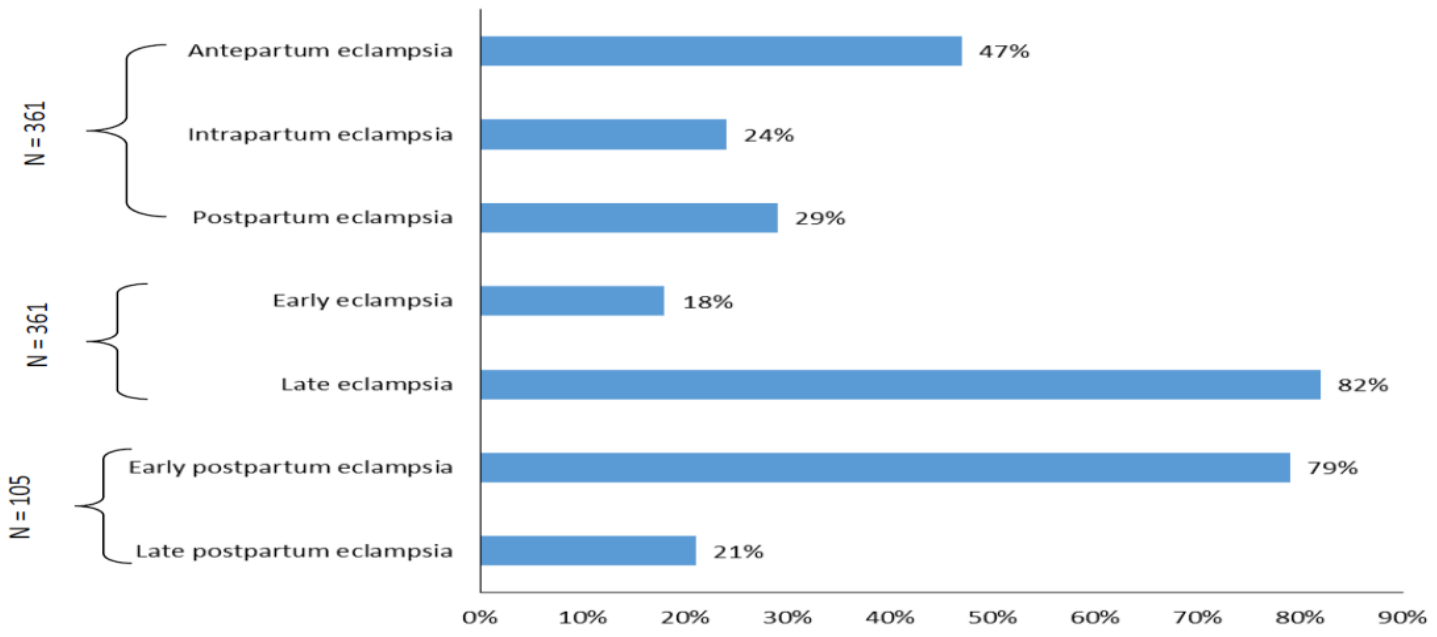

Figure 2: The distribution of eclampsia by timing of onset in relation to gestational age and delivery, 20082013.

Note. Onset of eclampsia was difined based on occurrence of first convulsion as:

1) Antepartum (during pregnancy), intrapartum (during labor and delivery) and postpartum (after deivery)

2) Early ( $<34$ weeks of gestation) and late ( $>=34$ weeks of gestation)

3) Early postpartum ( $<48$ hours after delivery) and late postpartum ( $>=48$ hours after delivery)

Table 1 shows the proportion of prepartum and postpartum eclampsia in relation to maternal age, selected clinical features and biomarkers. The ratio of eclampsia in youth and adults was almost $1: 1$. However, the proportion of postpartum eclampsia was significantly higher in adults than in youths $(63.8 \%$ vs $36.2 \%$; $\mathrm{P}=0.001)$. In terms of gestational age, more than two-thirds of the women with postpartum eclampsia (69.7\%) experienced it at term. In other words, preterm eclampsia was significantly higher in prepartum than in postpartum eclampsia $(\mathrm{P}<0.0001)$.

The overall incidence of eclampsia was a little bit higher in multigravida than in primigravida women $(53.2 \%$ vs $46.8 \%)$. Of interest, this analysis has strongly demonstrated that prepartum and postpartum eclampsia were mainly the diseases of primigravida and multigravida, respectively $(\mathrm{P}<0.0001)$. Out of the total primigravida eclamptic women, $96.4 \%$ (163/169) developed it during the prepartum period. Similarly, out of the total postpartum eclampsia cases, $94.3 \%$ occurred in multigravida women.

Among selected clinical features, severe systolic hypertensions $(>=160 \mathrm{mmHg})$ were characteristics of prepartum eclampsia (60.2\%). In other words, the majority of postpartum eclamptic women were having mild to moderate systolic hypertension $(53.3 \%$; $\mathrm{P}<0.05)$. However, the difference in diastolic hypertension in the two groups was not statistically significant. In the majority of both the prepartum and postpartum eclamptic women, the commonest severity symptom was headache $(80.5 \%$ and $66.7 \%$, respectively), with statistically significant difference between the two groups $(\mathrm{P}=0.004)$. Epigastric pain was an uncommon symptom among postpartum eclamptic women $(\mathrm{P}<0.0001)$. There were no statistically significant differences between the two groups in relation to other clinical features like urine output and episodes of convulsion before and after initiation of anticonvulsants.

In the majority of selected biomarkers, this analysis has demonstrated statistically significant difference between women with prepartum and postpartum eclampsia. Significant proteinuria $(\mathrm{P}<0.001)$ and severe thrombocytopenia $(\mathrm{P}=$ $0.009)$ were more common in women with prepartum than postpartum eclampsia. On the other hand, a high proportion of anemia $(\mathrm{P}<0.001)$ and $>=2$-fold raised in SGOT level was observed among women with postpartum eclampsia $(\mathrm{P}=$ $0.005)$. The $>=1 \mathrm{mg}$ raised in creatinine level in both prepartum and postpartum eclampsia was proportional, and occurred in nearly three-fifths of the total eclamptic women $(59.6 \%)$.

In terms of place of delivery, the proportion in one group was the mirror image of the other: $82 \%$ of prepartum eclamptic women gave birth in a health facility; $81.6 \%$ of postpartum eclamptic 
women gave birth at home without the assistance of skilled persons $(\mathrm{P}<0.0001)$. Almost all women with postpartum eclampsia and nearly threefourths of women with prepartum eclampsia delivered vaginally $(\mathrm{P}<0.0001)$.

The fetal birth weights in prepartum and postpartum eclamptic group were also significantly different: $75 \%$ of newborns of prepartum eclamptic women were having low birth weight; whereas, $87.6 \%$ of postpartum eclamptic women gave birth to newborns with normal birth weight $(\mathrm{P}<0.0001)$. As one of the outcome indicators, the proportion of perinatal death in women with prepartum eclampsia was significantly higher than the postpartum eclampsia $(\mathrm{P}<0.0001)$. With regard to the mothers, there was no statistically significant difference in maternal death and maternal hospital stay in the two groups.

Table 1: Clinical and biomarker features of prepartum and postpartum eclampsia, 2008-2013

\begin{tabular}{|c|c|c|c|c|}
\hline Variables & $\begin{array}{c}\text { Total } \\
\mathbf{N}=361\end{array}$ & $\begin{array}{l}\text { Prepartum } \\
\quad(\%) \\
\mathbf{N}=256\end{array}$ & $\begin{array}{c}\text { Postpartum } \\
(\%) \\
N=105\end{array}$ & P-value \\
\hline $\begin{array}{lc}\text { Age in years: } & 15-24 \\
& 25-49\end{array}$ & $\begin{array}{l}179(49.6) \\
182(50.4)\end{array}$ & $\begin{array}{l}141(55.1) \\
115(44.9)\end{array}$ & $\begin{array}{l}38(36.2) \\
67(63.8)\end{array}$ & 0.001 \\
\hline $\begin{array}{l}\text { Gestational age: } \\
\text { Preterm }(<37 \text { weeks }) \\
\text { Term }(>=37 \text { weeks })\end{array}$ & $\begin{array}{l}110(30.3) \\
251(69.7)\end{array}$ & $\begin{array}{l}96(37.5) \\
160(62.5)\end{array}$ & $\begin{array}{l}14(13.3) \\
91(86.7)\end{array}$ & $<0.0001$ \\
\hline $\begin{array}{l}\text { Parity: } \\
\quad \text { Primigravida } \\
\text { Multigravida }\end{array}$ & $\begin{array}{l}169(46.8) \\
192(53.2)\end{array}$ & $\begin{array}{l}163(63.4) \\
93(36.6)\end{array}$ & $\begin{array}{c}6(5.7) \\
99(94.3)\end{array}$ & $<0.0001$ \\
\hline $\begin{array}{ll}\text { Prenatal care: } & \text { Yes } \\
& \text { No }\end{array}$ & $\begin{array}{l}181(50.1) \\
180(49.9)\end{array}$ & $\begin{array}{l}138(53.9) \\
118(46.1)\end{array}$ & $\begin{array}{l}43(40.9) \\
62(59.1)\end{array}$ & $<0.05$ \\
\hline $\begin{array}{l}\text { Fetuses number: } \\
\text { Singleton } \\
\text { Twins }\end{array}$ & $\begin{array}{c}330(91.4) \\
31(8.6)\end{array}$ & $\begin{array}{l}234(91.4) \\
22(8.6)\end{array}$ & $\begin{array}{c}96(91.4) \\
9(8.6)\end{array}$ & 0.9 \\
\hline $\begin{array}{l}\text { Systolic hypertension (ever): } \\
\quad<160 \mathrm{mmHg} \\
>=160 \mathrm{mmHg}\end{array}$ & $\begin{array}{l}158(43.8) \\
203(56.2)\end{array}$ & $\begin{array}{l}102(39.8) \\
154(60.2)\end{array}$ & $\begin{array}{l}56(53.3) \\
49(46.7)\end{array}$ & $<0.05$ \\
\hline $\begin{array}{l}\text { Diastolic hypertension (ever): } \\
\quad<110 \mathrm{mmHg} \\
>=110 \mathrm{mmHg}\end{array}$ & $\begin{array}{l}191(52.9) \\
170(47.1)\end{array}$ & $\begin{array}{l}134(52.3) \\
122(47.7)\end{array}$ & $\begin{array}{l}57(54.3) \\
48(45.7)\end{array}$ & 0.8 \\
\hline $\begin{array}{ll}\text { Headache: } & \text { Yes } \\
& \text { No }\end{array}$ & $\begin{array}{c}276(76.5) \\
85(23.5)\end{array}$ & $\begin{array}{c}206(80.5) \\
50(19.5)\end{array}$ & $\begin{array}{l}70(66.7) \\
35(33.3)\end{array}$ & 0.004 \\
\hline $\begin{array}{ll}\text { Visual disturbance: } & \text { Yes } \\
& \text { No }\end{array}$ & $\begin{array}{l}161(44.6) \\
200(55.4)\end{array}$ & $\begin{array}{l}121(47.3) \\
135(52.7)\end{array}$ & $\begin{array}{l}40(38.1) \\
\quad 65(61.9)\end{array}$ & 0.1 \\
\hline $\begin{array}{ll}\text { Epigastric pain: } & \begin{array}{l}\text { Yes } \\
\text { No }\end{array}\end{array}$ & $\begin{array}{l}129(35.7) \\
232(64.3)\end{array}$ & $\begin{array}{l}110(43.0) \\
146(57.0)\end{array}$ & $\begin{array}{l}19(18.1) \\
86(81.9)\end{array}$ & $<0.0001$ \\
\hline $\begin{aligned} \text { Total episodes of convulsion before arrival: } & <10 \\
>= & 10\end{aligned}$ & $\begin{array}{l}277(76.7) \\
84(23.3)\end{array}$ & $\begin{array}{c}200(78.1) \\
56(21.9)\end{array}$ & $\begin{array}{l}77(73.3) \\
28(26.7)\end{array}$ & 0.4 \\
\hline $\begin{array}{l}\text { Any convulsion after initiation of anticonvulsant: } \\
\text { Yes } \\
\text { No }\end{array}$ & $\begin{array}{c}35(9.7) \\
326(90.3)\end{array}$ & $\begin{array}{c}25(9.8) \\
231(90.2)\end{array}$ & $\begin{array}{r}10(9.5) \\
95(90.5)\end{array}$ & 0.9 \\
\hline $\begin{array}{c}\text { Aspiration pneumonia: } \\
\text { Yes } \\
\text { No }\end{array}$ & $\begin{array}{r}64(17.7) \\
297(82.3)\end{array}$ & $\begin{array}{c}53(20.7) \\
203(79.3)\end{array}$ & $\begin{array}{l}11(10.5) \\
94(89.5)\end{array}$ & $<0.05$ \\
\hline $\begin{array}{l}\text { Urine output: } \\
\text { Normal } \\
\text { Oliguria/Anuria }\end{array}$ & $\begin{array}{l}156(43.2) \\
205(56.8)\end{array}$ & $\begin{array}{l}113(44.1) \\
143(55.9)\end{array}$ & $\begin{array}{l}43(41.0) \\
62(59.0)\end{array}$ & 0.5 \\
\hline $\begin{array}{l}\text { Proteinuria (qualitative): } \\
\text { Insignificant } \\
\text { Significant }\end{array}$ & $\begin{array}{l}122(33.8) \\
239(66.2)\end{array}$ & $\begin{array}{c}73(28.5) \\
183(71.5)\end{array}$ & $\begin{array}{l}49(46.7) \\
56(53.3)\end{array}$ & $<0.001$ \\
\hline
\end{tabular}


Table 1. Cont...

\begin{tabular}{|c|c|c|c|c|}
\hline Variables & $\begin{array}{c}\text { Total } \\
\mathbf{N}=361\end{array}$ & $\begin{array}{c}\text { Prepartum (\%) } \\
\quad \mathrm{N}=256\end{array}$ & $\begin{array}{c}\text { Postpartum (\%) } \\
\quad N=105\end{array}$ & P-value \\
\hline $\begin{array}{l}\text { Anemia }(\mathbf{H g b}<\mathbf{1 2} \mathbf{g m} / \mathbf{d l}) \text { : } \\
\text { Yes } \\
\text { No }\end{array}$ & $\begin{array}{c}85(23.5) \\
27(76.5)\end{array}$ & $\begin{array}{c}48(18.8) \\
208(81.2)\end{array}$ & $\begin{array}{l}37(35.2) \\
68(64.8)\end{array}$ & $<0.001$ \\
\hline $\begin{array}{cc}\text { Severe thrombocytopenia } \\
(<100,000 / \mathrm{mm} 3): & \text { Yes } \\
& \text { No }\end{array}$ & $\begin{array}{l}122(33.8) \\
239(66.2)\end{array}$ & $\begin{array}{c}76(29.7) \\
180(70.3)\end{array}$ & $\begin{array}{l}46(43.8) \\
59(56.2)\end{array}$ & 0.009 \\
\hline $\begin{array}{l}\text { Raised creatinine } \\
\left(>=1 \text { gm/dl): } \quad \begin{array}{l}\text { Yes } \\
\text { No }\end{array}\right.\end{array}$ & $\begin{array}{l}215(59.6) \\
146(40.4)\end{array}$ & $\begin{array}{l}153(59.8) \\
103(40.2)\end{array}$ & $\begin{array}{l}62(59.1) \\
43(40.9)\end{array}$ & 0.9 \\
\hline $\begin{array}{l}\text { Highest SGOT level: } \\
<2 \text {-fold raised } \\
>=2 \text {-fold raised }\end{array}$ & $\begin{array}{l}186(51.5) \\
175(48.5)\end{array}$ & $\begin{array}{l}144(56.3) \\
112(43.7)\end{array}$ & $\begin{array}{l}42(40.0) \\
63(60.0)\end{array}$ & 0.005 \\
\hline $\begin{array}{l}\text { Required antihypertensive: } \\
\text { Yes } \\
\text { No }\end{array}$ & $\begin{array}{l}256(70.9) \\
105(29.1)\end{array}$ & $\begin{array}{c}190(74.2) \\
66(25.8)\end{array}$ & $\begin{array}{l}66(62.9) \\
39(37.1)\end{array}$ & $<0.05$ \\
\hline $\begin{array}{l}\text { Anticonvulsant given: } \\
\text { MgSo4 } \\
\text { Diazepam }\end{array}$ & $\begin{array}{l}228(63.2) \\
133(36.8)\end{array}$ & $\begin{array}{c}168(65.6) \\
88(34.4)\end{array}$ & $\begin{array}{l}60(57.1) \\
45(42.9)\end{array}$ & 0.1 \\
\hline $\begin{array}{l}\text { Place of delivery: } \\
\text { Health facility } \\
\text { Home }\end{array}$ & $\begin{array}{l}229(63.4) \\
132(36.6)\end{array}$ & $\begin{array}{c}210(82.0) \\
46(18.0)\end{array}$ & $\begin{array}{l}19(18.4) \\
86(81.6)\end{array}$ & $<0.0001$ \\
\hline $\begin{array}{l}\text { Mode of delivery: } \\
\text { Vaginal } \\
\text { Caesarean }\end{array}$ & $\begin{array}{c}287(79.5) \\
74(20.5)\end{array}$ & $\begin{array}{c}183(71.5) \\
73(28.5)\end{array}$ & $\begin{array}{c}104(99.0) \\
1(1.0)\end{array}$ & $<0.0001$ \\
\hline $\begin{array}{c}\text { Newborns sex: } \\
\text { Male } \\
\text { Female }\end{array}$ & $\begin{array}{l}222(61.5) \\
139(38.5)\end{array}$ & $\begin{array}{l}153(59.8) \\
103(40.2)\end{array}$ & $\begin{array}{l}69(65.7) \\
36(34.3)\end{array}$ & 0.3 \\
\hline $\begin{array}{c}\text { Newborn birth weight }(\mathbf{k g}) \text { : } \\
\quad<2.5 \\
>=2.5\end{array}$ & $\begin{array}{l}205(56.8) \\
156(43.2)\end{array}$ & $\begin{array}{c}192(75.0) \\
64(25.0)\end{array}$ & $\begin{array}{l}13(12.4) \\
92(87.6)\end{array}$ & $<0.0001$ \\
\hline $\begin{array}{l}\text { Maternal outcome: } \\
\text { Discharged alive } \\
\text { Dead }\end{array}$ & $\begin{array}{c}320(88.6) \\
41(11.4)\end{array}$ & $\begin{array}{l}227(88.7) \\
29(11.3)\end{array}$ & $\begin{array}{l}93(88.6) \\
12(11.4)\end{array}$ & 0.9 \\
\hline $\begin{array}{l}\text { Perinatal outcome: } \\
\text { Discharged alive } \\
\text { Dead }\end{array}$ & $\begin{array}{l}228(63.2) \\
133(36.8)\end{array}$ & $\begin{array}{l}139(54.3) \\
117(45.7)\end{array}$ & $\begin{array}{l}89(84.8) \\
16(15.2)\end{array}$ & $<0.0001$ \\
\hline
\end{tabular}

\section{DISCUSSION}

The incidence of eclampsia in this study was more than four-fold higher than a global estimate $(1.2 \%$ vs $0.28 \%$ ) (7). Yet, our report was nearly in line with other reports from Nepal and Tanzania $(31,32)$, and more than 3-fold lower than the reports from some centers in Nigeria and Pakistan $(24,33,34)$. Specifically, the incidence of postpartum eclampsia (more than a quarter of the total) is consistent with several reports from both high and low income countries $(26,29,35,36)$. The proportion of late postpartum eclampsia $(21 \%)$ was also in between some previous reports, $14 \%$ and $15 \%(22,37)$ and $28 \%$ and $56 \%(36,38)$.

Of interest, this analysis has shown that the clinical and biochemical spectrum of prepartum and postpartum eclampsia were different. Our main findings were that women with prepartum eclampsia were relatively young age, and the majority were primigravida, more hypertensive, symptomatic and proteinuric. Conversely, the majority of women who were at increased risk for post-partum eclampsia were adult, multiparous, having term pregnancy, anemic, thrombocytopenic, and with hepatic dysfunction.

The association of prepartum eclampsia with young age and primigravida is consistent with one previous report that assessed only antepartum and intrapartum eclampsia (39). Several other studies also showed the increased risk of eclampsia among primigravid and young women. However, none of these studies compared the predictor 
variables by stratifying the type of eclampsia as pre- and post-delivery; they reported that eclampsia is common in primigravida, age $<25$ years by including either all types of eclampsia or only postpartum eclampsia as a denominator $(5,21,27,37,38,40)$.

The increased risk of prepartum eclampsia among young and nulliparous women may not be as such controversial. As this study showed, however, the postpartum eclampsia was strongly associated with women who were multiparous and aged 25 years and above. Nevertheless, this finding is not in line with two previous studies, which assessed only postpartum eclampsia and reported the increased risk to primigravida and young age $(37,38)$. As a result, we recommend further study to verify the age and parity spectrum in prepartum and postpartum eclampsia.

The significant association of prepartum and postpartum eclampsia with preterm and term pregnancies, respectively, was expected. This is because the majority of prepartum eclampsia cases $(47 \%)$ were antepartum by onset; and antepartum eclampsias in turn were reported as being strongly associated with preterm pregnancies (Douglas and Redman, 1994) (40). This study also showed that about $38 \%$ of prepartum eclampsia occurred in preterm pregnancies while the proportion of preterm postpartum eclampsia was nearly threefold lower (13\%). As a complimentary evidence, three-fourths of babies born to prepartum eclampsia were having low birth weight while the reverse was true for postpartum eclampsia.

Similarly, the significantly increased anemia, thrombocytopenia and evidence of hepatic dysfunction in women with postpartum eclampsia could be explained in two ways. Since the majority of women with postpartum eclampsia gave birth at home with no skilled person attendant, the possibility of more blood loss during delivery was probably unavoidable. Secondly, the relatively low proportion of headache and the lowest proportion of epigastric pain and blurring of vision among postpartum eclamptic women might have increased the chance for the disease to buy more time which might have resulted in more organs damage.

In this study, headache was the commonest prodromal symptom in both prepartum and postpartum eclampsia, which is consistent with several other studies $(21,26,40)$. The relatively low proportion of epigastric pain and visual disturbance in women with postpartum eclampsia was also reported in Onuh et al study (40). The low proportion of severity symptoms in women with postpartum eclampsia might have contributed to failure of preventive actions prior to its occurrence.

Lastly, the significantly increased risk of perinatal mortality in women with prepartum eclampsia may not only be associated with the hypertensive disease itself. Since the majority of babies in preeclamptic women were born preterm and with low birth weight, the chance of survival in the early neonatal period might be low, which was also observed in other studies $(7,31,40)$.

This study is not without limitation. Since our study is based on referral hospitals data, where the majority of eclamptic women were likely to come, the reported incidence may not represent the actual incidence of eclampsia in the general population. The denominator in the community is expected to be high due to the large number of deliveries at home and in the referring health facilities. Furthermore, since the majority of the included women were admitted to the study hospitals after the onset of convulsion, we were unable to assess their pre-convulsion status. Because of the delay in reporting, patients or relatives might not recall the exact time of onset of convulsion. As a result, some of the early onset postpartum eclampsia might be grouped as late onset. The documented histories, physical examinations and laboratory findings may not be always accurate.

In conclusion, the incidence of eclampsia in this study was high, but not as high as some other reports. More than a quarter of the total were postpartum eclampsia. This analysis demonstrated that prepartum eclampsia was mainly the disease of nulliparous and young women. On the other hand, the majority of women who developed postpartum eclampsia were multiparous and adult. The commonest severity symptom was headache, but was less common in postpartum than prepartum eclamptic women. Derangement of biomarkers was more common in postpartum eclampsia. Since this is probably the first study that assessed the association of several variables with prepartum and postpartum eclampsia, similar studies are highly recommended. 


\section{ACKNOWLEDGEMENT}

We would like to thank UNFPA, Ethiopia, for the very modest financial support.

\section{REFERENCES}

1. Duley L. The global impact of pre-eclampsia and eclampsia. Semin Perinatol, 2009; 33:130-7.

2. Ghulmiyyah L, Sibai B. Maternal mortality from preeclampsia/eclampsia. Semin Perinatol, 2012; 36(1):56-9.

3. Norwitz ER, Lockwood CJ, Barss VA. Eclampsia, 2014. UpToDate. http://www.uptodate.com/contents/eclampsia.

4. Sibai BM. Magnesium sulfate prophylaxis in preeclampsia: Lessons learned from recent trials. Am J Obstet Gynecol, 2004; 190(6):1520-6.

5. Eke AC, Ezebialu IU, Okafor C. Presentation and outcome of eclampsia at a tertiary center in South East Nigeria--a 6-year review. Hypertens Pregnancy, 2011; 30(2):125-32.

6. Miguil M, Chekairi A. Eclampsia, study of 342 cases. Hypertens Pregnancy, 2008; 27(2): 103.

7. Abalos E, Cuesta C, Carroli G, Qureshi Z, Widmer M, Vogel JP, Souza JP. Preeclampsia, eclampsia and adverse maternal and perinatal outcomes: a secondary analysis of the World Health Organization Multicountry Survey on Maternal and Newborn Health. BJOG, 2014; 121(Suppl. 1): 14-24.

8. World Health Organizatio (WHO). WHO recommendation for prevention of preeclamapsia and eclampsia. 2011. Geneva/Switzerland. Retrieved from: www.who.int/reproductivehealth/publications/ maternal_perinatal_health/

9. Davey D.A. and MacGillivray I. The classification and definition of hypertensive disorders of pregnancy. American Journal of Obstetrics and Gynecology, 1988; 158: 892 898.

10. Ekele BA, Bello SO, Adamu AN. Clusters of eclampsia in a Nigerian teaching hospital. Int J Gynaecol Obstet, 2007; 96(1):62-6.

11. Abd El Aal DE, Shahin AY. Management of eclampsia at Assiut University Hospital, Egypt. Int J Gynaecol Obstet, 2012; 116(3): 232-6.

12. Thangaratinam S, Langenveld J, Mol BW, Khan KS. Prediction and primary prevention of pre-eclampsia. Best Pract Res Clin Obstet Gynaecol, 2011; 25: 419-33 (Study 1).

13. Thangaratinam S, Gallos ID, Meah N, Usman $\mathrm{S}$, Ismail KM, Khan KS. How accurate are maternal symptoms in predicting impending complications in women with preeclampsia? A systematic review and meta-analysis. Acta Obstet Gynecol Scand, 2011; 90: 564-73 (Study 2).

14. Alexander JM, McIntire DD, Leveno KJ, Cunningham FG. Selective magnesium sulfate prophylaxis for the prevention of eclampsia in women with gestational hypertension. Obstet Gynecol, 2006; 108(4):826-32.

15. Foong SC, Pollard JK. Eclampsia in Southern Alberta: is there a role for seizure prophylaxis in all women with gestational hypertension? $J$ Obstet Gynaecol Can, 2003; 25(5):385-9.

16. Katz VL, Farmer R, Kuller JA. Preeclampsia into eclampsia: toward a new paradigm. Am J Obstet Gynecol, 2000; 182(6):1389-96.

17. Liu S, Joseph KS, Liston RM, Bartholomew S, Walker M, León JA, Kirby RS, Sauve R, Kramer MS. Incidence, risk factors, and associated complications of eclampsia. Obstet Gynecol, 2011; 118(5):987-94.

18. Morikawa M, Cho K, Yamada T, Yamada T, Sato S, Minakami H. Risk factors for eclampsia in Japan between 2005 and 2009. Int J Gynaecol Obstet, 2012; 117(1):66-8.

19. Vigil-De Gracia P. Maternal deaths due to eclampsia and HELLP syndrome. Int $\mathbf{J}$ Gynaecol Obstet, 2009; 104(2):90-4.

20. Urassa DP, Carlstedt A, Nyström L, Massawe SN, Lindmark G. Eclampsia in Dar es Salaam, Tanzania -- incidence, outcome, and the role of antenatal care. Acta Obstet Gynecol Scand, 2006; 85(5):571-8.

21. Ade-Ojo IP, Loto OM. Outcome of eclampsia at the Obafemi Awolowo University Teaching Hospital Complex, Ile-Ife. Niger J Clin Pract, 2008; 11(3):279-84.

22. Kayem G, Kurinczuk JJ, Spark P, Brocklehurst P, Knight M; UK Obstetric Surveillance System (UKOSS). Maternal and obstetric factors associated with delayed postpartum eclampsia: a national study population. Acta Obstet Gynecol Scand, 2011; 90(9):1017-23.

23. Al-Safi Z, Imudia AN, Filetti LC, Hobson DT, Bahado-Singh RO, Awonuga AO. Delayed postpartum preeclampsia and eclampsia: demographics, clinical course, and complications. Obstet Gynecol, 2011; 118(5):1102-7. 
24. Yakasai IA, Gaya SA. Maternal and fetal outcome in patients with eclampsia at Murtala Muhammad specialist Hospital Kano, Nigeria. Ann Afr Med, 2011; 10(4):305-9.

25. Arora R, Ganguli R P, Swain S, Oumachigui A, Rajaram P. Determinants of Maternal Mortality in Eclampsia in India. Aust NZ J Obstet Gynuecol, 1994; 34 (5): 537.

26. Cooray SD, Edmonds SM, Tong S, Samarasekera SP, Whitehead CL. Characterization of symptoms immediately preceding eclampsia. Obstet Gynecol, 2011; 118(5):995-9.

27. Pal A, Bhattacharyya R, Adhikari S, Roy A, Chakrabarty D, Ghosh P, Banerjee C. Eclampsia-scenario in a hospital--a ten years study. Bangladesh Med Res Counc Bull, 2011; 37(2):66-70.

28. Adekanle D A, Akinbile TO. Eclampsia and Pregnancy Outcome at Lautech Teaching Hospital, Osogbo, South West, Nigeria. Clinics in Mother and Child Health, 2012; 9. doi:10.4303/cmch/C120301.

29. Andersgaard AB, Herbst A, Johansen $M$, Ivarsson A, Ingemarsson I, Langhoff-Roos J, Henriksen T, Straume B, Oian P. Eclampsia in Scandinavia: incidence, substandard care, and potentially preventable cases. Acta Obstet Gynecol Scand, 2006; 85(8):929-36.

30. Central Statistical Agency [Ethiopia] and ICF International. 2012. Ethiopia Demographic and Health Survey 2011. Addis Ababa, Ethiopia and Calverton, Maryland, USA: Central Statistical Agency and ICF International. Accessible at: dhsprogram.com/pubs/pdf/FR255/FR255.pdf

31. Ndaboine EM, Kihunrwa A, Rumanyika R, Im $\mathrm{HB}$, Massinde AN. Maternal and perinatal outcomes among eclamptic patients admitted to Bugando Medical Centre, Mwanza, Tanzania. Afr $J$ Reprod Health, 2012; 16(1):35-41.

32. Thapa K, Jha R. Magnesium sulphate: a lifesaving drug. JNMA J Nepal Med Assoc, 2008; 47(171):104-8.

33. Noor S, Halimi M, Faiz NR, Gull F, Akbar N. Magnesium sulphate in the prophylaxis and treatment of eclampsia. J Ayub Med Coll Abbottabad, 2004; 16(2):50-4.

34. Tukur J, Umar BA, Rabi'u A. Pattern of eclampsia in a tertiary health facility situated in a semi-rural town in Northern Nigeria. Ann Afr Med, 2007; 6(4):164-7.

35. Knight M; UKOSS. Eclampsia in the United Kingdom 2005. BJOG, 2007; 114(9):1072-8.

36. Zwart JJ, Richters A, Ory F, de Vries JI, Bloemenkamp $\mathrm{KW}$, van Roosmalen $\mathrm{J}$. Eclampsia in the Netherlands. Obstet Gynecol, 2008; 112(4):820-7.

37. Chhabra S, Tyagi S, Bhavani M, Gosawi M. Late postpartum eclampsia. J Obstet Gynaecol, 2012; 32(3):264-6. ,

38. Lubarsky SL, Barton JR, Friedman SA, Nasreddine S, Ramadan MK, Sibai BM. Late postpartum eclampsia revisited. Obstet Gynecol,1994; 83(4):502-5.

39. Koum K, Hy S, Tiv S, Sieng T, Obara H, Matsui M, Fujita N. Characteristics of antepartum and intrapartum eclampsia in the National Maternal and Child Health Center in Cambodia. J Obstet Gynaecol Res, 2004; 30(2):74-9.

40. Onuh SO, Aisien AO. Maternal and fetal outcome in eclamptic patients in Benin City, Nigeria. J Obstet Gynaecol, 2004; 24(7):765.

41. Douglas K A, Redman CWG. Eclampsia in the United Kingdom. BMJ, 1994; 309:1395. 